\title{
EDITORIAL
}

\section{ENFERMAGEM E VALORES ÉTICOS: TITULO DE DOUTOR HONORIS CAUSA}

Quais as honrarias que diferentes órgãos e o País têm conferido a pessoas consideradas expoentes de valores éticos na área de enfermagem?

De fatos da enfermagem nacional felizmente há numerosos registros. Muitos constam do livro de Anayde Corrêa de Carvalho, Associação Brasileira de Enfermagem Documentário 1926/1976. A ABEn sem dúvida, quer dar continu idade a essa memória.

$\mathrm{Na}$ história de tais fatos madame Durocher e Ana Néri, no século passado, foram honradas respectivamente como membro da Academia Nacional de Medicina e condecorada de Guerra. Outras duas enfermeiras em 1946 receberam Medalha de Guerra. Cem exemplares da Medalha Florence Nightingale cunhada pela UFRJ, 1960, assinalam destinatários ilustres na área da enfermagem. A Ordem Cruzeiro do Sul foi conferida pelo Presidente da Répública à Sra. Clara Curtis, não só membro do grupo inicial trazido pela Fundação Rockefeller para os inícios de ensino e trabalho de enfermagem do Sistema Nightingale, no Rio de Janeiro, como também administradora de enfermagem na Fundação SESP e sócia da ABEn, nos anos 1940 a meados dos anos 1950.

Títulos de valor social elevado têm sido conferidos, quer pela própria ABEn - Sócio honorário - quer por Assembléias Legislativas e Câmaras de Vereadores. Não está esgotada a presente listagem. $O$ presente editorial é para referir uma honraria recente.

A 3 de maio de 1983, a Universidade Federal do Rio de Janeiro, que é a mais antiga do País, conferiu o título de Doutor Honoris Causa à Profa Waleska Paixão, e na citação, foram referidos: quatorze an os de sua djreção na unidade Escola de Enfermagem An a Néri, sua contribuição à enferma gem nacional, não só em Minas Gerais - onde fôra também diretora de escola congênere - como em todo o Brasil, pelos serviços continuados em prol da assistência de enfermagem, ocupações de enfermagem e educação, e, finalmente, sua presença, nos últimos anos e atual, num município carente do NORDESTE, no Estado de Sergipe.

Registra-se com grande satisfação e sta honraria uma vez que, $m$ ais do que à própria agracia da - sabidamente com sua humildade de serva daqueles a quem o Senhor the dá - o título honra à enfermagem brasileira. (HGD) 